\title{
ПЕРЕХІД ВІД ПЕДІАТРИЧНОЇ МЕДИЧНОЇ ДОПОМОГИ ДО ОРІЄНТОВАНОЇ НА ДОРОСЛИХ СИСТЕМИ ОХОРОНИ ЗДОРОВ'Я: ВИКЛИК ДЛЯ ПАЦІЄНТІВ 3 ЮВЕНІЛЬНИМ ІДІОПАТИЧНИМ АРТРИТОМ
}

\author{
О. В. Підкова \\ Комунальне некомериійне підприємство Львівської обласної ради \\ «Західноукрайнський спеціалізований дитячий медичний центр»
}

У статті подано короткий опис ювенільного ідіопатичного артриту: поширеність, етіологія та необхідність цілеспрямованого запланованого переходу підлітків, хворих на ювенільний ідіопатичний артрит, від педіатричної допомоги до орієнтованої на дорослих системи охорони здоров’я.

\section{THE TRANSITION FROM PEDIATRIC TO ADULT-ORIENTED HEALTH CARE: A CHALLENGE FOR PATIENTS WITH JUVENILE IDIOPATHIC ARTHRITIS}

\author{
O. V. Pidkova
}

\section{Western-Ukrainian Specialized Children's Medical Centre}

The article provides a brief description of juvenile idiopathic arthritis (JIA): prevalence, pathogenesis, etiology. The article describes the necessity and importance of resolutive, planned transition of teenagers with JIA from pediatric medical care to adult-oriented health care systems.

Вступ. Ювенільний ідіопатичний артрит (ЮІА) найпоширеніше і тяжке хронічне захворювання суглобів у дитячому віці. 3 роками загальновживаний термін для опису цієї патології змінювався. Дослідження, проведені у багатьох країнах, свідчать про різну поширеність ЮІА, яка коливається від 16 до 401 випадку на 100000 дітей. На основі даних із Європи, Північної Америки, Австралії, у світі налічують від 1,7 до 8,4 мільйона дітей із хронічним артритом [3-5]. В останні десятиліття до цієї патології включено всі види артриту, які не мають визначених причин, тривають понад 6 тижнів, у пацієнтів молодших 16 років.

Незважаючи на сучасні досягнення в медицині, причини розвитку ЮІА залишаються нез'ясованими. Проте, з появою нових терапевтичних препаратів, протягом останніх 15 років спостерігають покращення в лікуванні ЮІА у дітей та досягнення позитивного довгострокового результату без наслідків. Завдяки цьому діти, підлітки та пацієнти молодого віку (ПМВ) мають змогу вести активне життя в школі, коледжі, університеті; насолоджуватись активним соціальним

(с) О. В. Підкова, 2020 та сімейним життям; ставати самостійними дорослими [2].

Основна частина. Важливим моментом у житті пацієнта з ЮІА $\epsilon$ перехід підлітків та ПМВ із ревматичними захворюваннями від педіатричної медичної допомоги до орієнтованої на дорослих системи охорони здоров'я. Молоді люди, у яких ЮІА дебютував у дитинстві, потребують допомоги у переході під спостереження фахівців, які опікуватимуться ними в дорослому віці. Забезпечення якісного процесу переходу належить співпраці мультидисциплінарної команди фахівців дитячого та дорослого віку, в якій інтегральну роль відіграє координатор перехідної допомоги. Роль перехідного координатора може, за своїми кваліфікаційними характеристиками, взяти на себе молодший спеціаліст із медичною освітою (медична сестра).

ЮІА - збірне поняття, що об'єднує різні форми артритів невідомої етіології, які дебютують у дітей до 16 років і тривають понад 6 тижнів [1,2]. Сьогодні використовують термін «ювенільний ідіопатичний артрит», де «ідіопатичний» означає, що причина не- 
відома, «ювенільний», що захворювання починається у дитячому віці. Найімовірнішим механізмом розвитку ЮІА $є$ взаємодія між факторами зовнішнього середовища, поєднання генетичної схильності та порушення імунної регуляції. Однозначних доказів на користь визначення етіології ЮІА доведено не було. На початку минулого століття існувала концепція щодо того, що мікроорганізми, які інфікують слизові (ротову порожнину, дихальні шляхи, кишечник), можуть викликати аутоімунні процеси, що спричиняють хронічні артрити. Будь-який фактор може бути випадковою подією у сприйнятливої людини або необхідним фактором розвитку ЮІА. Етіологія та патогенез є багатофакторними та об'єднані спільним результатом розвитку артриту.

На сьогодні відомо сім варіантів перебігу ЮІА: системний, олігоартрит, поліартрит із негативним ревматоїдним фактором, поліартрит із позитивним ревматоїдним фактором, артрит, асоційований 3 ентезитом, псоріатичний артрит та інші артрити [1]. Ці форми відрізняються за віком початку хвороби, статтю, наявністю чи відсутністю системних проявів хвороби (гарячка, висипання, ураження внутрішніх органів), кількістю та характером ураження суглобів у перші шість місяців хвороби, а також на основі результатів лабораторних досліджень.

Артрит (запалення суглоба) характеризується набряком суглоба, який розвивається внаслідок запалення синовіальної оболонки суглоба, її потовщення та секреції підвищеної кількості синовіальної рідини. Характерною ознакою ЮІА $є$ утворення пануса - пухлиноподібного розростання синовіальної тканини, який спричиняє ураження суглоба і деградацію внутрішньосуглобового хряща, а згодом повну нерухомість суглоба (анкілозування). Виходячи з цього, важливим для пацієнтів $є$ покращення якості життя, адаптація у колективах, заняття спортом.

Прогноз ЮІА у дітей є сприятливішим, порівняно 3 прогнозом у дорослих, які хворіють на ревматоїдний артрит, та залежить від тяжкості, форми перебігу хвороби та від часу початку лікування. Лікування дає змогу більшості дітей з ЮІА досягти ремісії хвороби, запобігти розвиткові хронічних уражень і деформацій суглобів. Не менш важливим $є$ забезпечення нормального фізичного, розумового та соціального розвитку дитини, яка захворіла на ЮІА. Необхідними є фізична реабілітація, психосоціальний супровід дитини та іiї родини для подолання труднощів, пов'язаних із хворобою.
Для лікування ЮІА застосовують такі групи препаратів, як нестероїдні протизапальні, базові (імунодепресанти/цитостатики), глюкокортикостероїди, біологічні.

Особливо актуальним на сьогодні $є$ застосування біологічних препаратів - ліків, що блокують розвиток запального процесу при ЮІА. Застосування цих ліків дає змогу досягти ремісії у хворих, які не відповіли на традиційну базову терапію, та запобігти розвиткові їхньої інвалідизації.

Регулярне приймання біологічних агентів дає шанс дітям та дорослим з ЮІА на повноцінне життя. Тому продовжувати лікування пацієнтів з ЮІА у віці старше 18 років є вкрай необхідним, оскільки без його продовження всі досягнуті результати будуть втрачені. Це та багато інших причин підтверджують необхідність розробляти і втілювати у клінічну практику алгоритм спадкоємності між дитячим та дорослим лікаремревматологом після досягнення пацієнтом з ЮІА віку 18 років.

У 2016 р. експерти Європейської протиревматичної ліги та Європейського товариства дитячих ревматологів оприлюднили рекомендації щодо перехідної допомоги пацієнтам молодого віку з ювенільними ревматичними захворюваннями та патологією опорно-рухового апарату [5, 6].

Рекомендації включають:

- високоякісну допомогу в ранньому підлітковому віці;

- інтегральну роль координатора перехідної допомоги;

- протоколи перехідної допомоги;

- принципи ефективної комунікації;

- трансфер документації;

- навчання спеціалістів;

- гарантоване фінансування лікування в дорослій ревматології.

Підлітки ти ПМВ повинні мати доступ до високоякісної, координованої, комплексної перехідної допомоги з мультидисциплінарним підходом, де враховуватимуть медичні, психологічні та професійні аспекти. Пацієнтам необхідно забезпечити якнайшвидший початок переходу: у ранньому підлітковому віці чи відразу після встановлення діагнозу. Найкраще починати його з 11 років та найпізніше в 14 років, акцентуючи увагу на розумінні підлітком турботи про власне здоров'я та формуванні навичок його підтримання. Перехідний процес - це явище індивідуальне і триватиме він і в дорослому віці. 
обов'язковим $є$ тісний зв'язок між ПМВ, їхніми батьками, педіатрами та терапевтами впродовж усього процесу переходу, а також постійний обмін інформацією між ними.

Індивідуальний процес переходу повинен постійно плануватись та документуватись ПМВ та їхніми родичами, це спонукатиме підлітків до самоконтролю.

Важливим моментом $є$ створення та наявність трансферного документа, який містить медичне заключення, інформацію про супутні захворювання, вакцинацію, наявність ускладнень та їх лікування, минуле та теперішнє лікування. Додатково документ повинен включати психосоціальні аспекти, дані про навчання чи роботу, про самоконтроль та готовність до переходу, методи та засоби для знеболювання. Трансферний документ має бути доступний пацієнту та наступній команді фахівців.

Для забезпечення якісного процесу переходу повинна працювати система фінансування, яка забез-

\section{СПИСОК ЛІТЕРАТУРИ}

1. Бойко Я. Є. Ювенільний ідіопатичний артрит : монографія / Я. Є. Бойко, В. П. Чернишов; за ред. Я. Є. Бойко. 2-ге вид., доповн. - Львів : Світ, 2019. - С. 10-25, С. 212-220.

2. Бойко Я. Є. Ювенільний ідіопатичний артрит : монографія / Я. Є. Бойко, В. П. Чернишов ; за ред. Я. Є. Бойко. 2-ге вид., доповн. - Львів : Світ, 2017. - С. 9-17, С. 167-171.

3. Khuffash F. A.Epidemiology of juvenile chronic arthritis and other connective tissue diseases among children in Kuwait / F. A. Khuffash, H. A. Majjed // Ann. Trop. Paediatr. 1990. - Vol. 10. - P. 255-259.

4. Steven M. M. Prevalence of chronic arthritis in four geographical areas of the Scottish Highlands / M. M. Steven // Ann. Rheum. Dis. - 1992. - Vol. 51. - P. 195-197. печить безперервне лікування, незалежно від віку пацієнта. Вчасно, якісно та результативно розпочате лікування у дитячому віці повинно отримати матеріальне забезпечення також для дорослого пацієнта.

Визначити ступінь готовності пацієнта до переходу під опіку ревматологів рекомендовано за допомогою TRAQ-валідного опитувальника, орієнтованого на пацієнта та його родину [1, 7].

Висновки. 1. Ювенільний ідіопатичний артрит це поширена патологія дитячого віку, яка впливає на якість життя пацієнтів, примушуючи їх постійно приймати ліки.

2. Дана патологія має хронічний перебіг, а тому важливим моментом у житті пацієнтів $є$ їх перехід до дорослого життя, це потребує співпраці команди фахівців, членом якої виступає медична сестра. Саме вона повинна взяти на себе роль координатора перехідної допомоги.

5. International League of Associatiation for Reumatology classification of juvenile idiopathic arthritis: second revision, Edmonton, 2001 / R. E. Petty, T. R. Southwood, P. Manners [et al.] // J. Rheum. - 2004. - Vol. 31 (2). - P 390-392.

6. Nigrovic P. A. Review: Genetics and the classification of arthritis in adult and children / P. A. Nigrovic, S. Raychaudhuri, S. D. Thompson // Arthritis Rheum. (Hoboken, Nj). - 2018. Vol. 70 (1). - P. 7-17.

7. EULAR/Pres standards and recommendations for the transitionalcare of young people with juvenile-onsetrheumatic diseases / H. E. Foster, K. Minden, D. Clemente [et al.] // Ann. Rheum. Dis. - 2016. - Vol. 76 (4). - P. 639-646.

Отримано 22.01.20 